\author{
Mirosław SADOWSKI \\ Uniwersytet Wrocławski \\ miroslaw.sadowski@uwr.edu.pl
}

\title{
APOLOGIA TO ZA MAŁO
}

\section{KILKA UWAG NA MARGINESIE KSIĄŻKI EUGENIUSZA SAKOWICZA ${ }^{1}$}

Wzmożone zainteresowanie islamem, które daje się zauważyć na przestrzeni ostatnich kilkunastu lat, przekłada się na wzrost liczby publikacji poświęconych tej religii lub ideom przez nią inspirowanym. Momentem przełomowym dla tej tendencji były bez wątpienia zamachy na USA z września 2001 r., przeprowadzone przez muzułmanów deklarujących inspiracje islamem. Kolejne zbrodnicze zamachy w Europie, przeprowadzone z podobnych pobudek w Madrycie (2004), Londynie (2005), a ostatnio w Paryżu w 2015 r., spotęgowały uzasadniony strach przed muzułmanami, a jednocześnie chęć zrozumienia motywów, którymi kierują się wyznawcy islamu, podejmując tego typu działania. Inną przyczyną jest stały wzrost populacji muzułmanów w krajach Okcydentu i częsty brak integracji tej grupy z resztą społeczeństwa. Pojawiają się nawet głosy przekonujące, że muzułmańskie diaspory często tworzą społeczeństwa równoległe w krajach, w których żyją. Z tych powodów liczba prac na temat islamu i jego wyznawców rośnie również w Polsce, gdzie oprócz tłumaczeń z języków obcych pojawia się wiele prac rodzimych autorów. Opublikowane książki przedstawiają islam i jego wyznawców w świetle korzystnym²

\footnotetext{
E. Sakowicz, Muzutmańska edukacja i wychowanie. Pedagogiczna wizja M. Fethullaha Gülena, Białystok 2014, 183 s. Współwydawcy książki Libra s.c. Wydawnictwo i Drukarnia oraz Dunaj. Instytut Dialogu sa instytucjami związanymi z Ruchem Gülena.

2 Dla przykładu mogę wskazać następujące pozycje z ostatnich lat: I. Mattson, Qur'an. Historia i rola Świętej Księgi w życiu muzutmanów, przeł. K. Makaruk, M. Turowski, Wrocław 2013; R. Aslan, Nie ma Boga oprócz Allaha. Powstanie, ewolucja i przysztość islamu, przeł. P. Gołębiowski, Warszawa 2014; M. Widy-Behiese, Tożsamość europejskich muzutmanów w myśli Tariqa Ramadana, Warszawa 2012; B. Pasamonik, Rola ptci w integracji europejskich muzutmanów, Kraków 2013.
} 
bądź krytycznym ${ }^{3}$. W ten pierwszy, pochwalny, a nawet apologetyczny nurt wpisuje się omawiana praca Eugeniusza Sakowicza.

Autor wydaje się osobą w pełni predysponowaną ${ }^{4}$ do podjęcia się analizy koncepcji pedagogicznych Muhammada Fethullaha Gülena. Kierownik Katedry Pedagogiki, teolog, religioznawca, redaktor i współautor kilku książek o islamie zapewne poradzi sobie z omówieniem i oceną interesującego przedsięwzięcia edukacyjno-społecznego - teorii i praktyki działania imperium edukacyjno-medialnego tureckiego miliardera. Gülen to działacz społeczny, edukator, właściciel sieci szkół w wielu krajach ${ }^{5}$ i magnat medialny. Ten wydawca gazet, właściciel kanału telewizyjnego w Turcji, inicjator lub założyciel wielu fundacji i stowarzyszeń od lat uznawany jest za jednego z 500 najbardziej wpływowych muzułmanów na świecie ${ }^{6}$. Bohater książki Sakowicza jest osobą, która nieustannie podkreśla swoje związki z islamem. Zachętą do zapoznania się z treścią przedmiotowej publikacji były także fragmenty recenzji wydawniczych zamieszczone na okładce. Ich autorzy przekonywali, że jest ona praktycznym przykładem tego, co łączy w tradycjach religijnych (P. Stawiński) i poszerza świadomość i wiedzę polskiego odbiorcy w zakresie nierozpoznanego [zaiste - przyp. M.S.] do tej pory edukacyjnego potencjatu islamu - religii pokoju, przebaczenia, tolerancji i otwartości (D. Stępkowski SDB).

Pierwsze spostrzeżenie, jakie nasunęło mi się w trakcie analizy pracy Sakowicza, dotyczy tytułu. W mojej ocenie autor nie ustrzegł się tutaj pewnego błędu logicznego, za jaki uważam umieszczenie w tytule dwóch terminów - edukacja i wychowanie - definiujących to samo. Uniwersalny stownik jezzyka polskiego, definiując edukację, wywodzi, że jest to uczenie kogoś lub uczenie się, zwtaszcza w szkole; ksztatcenie, nauka. W drugim znaczeniu stwierdza, że jest to ksztattowanie u kogoś określonych postaw i reakcji, wychowywanie ${ }^{7}$. Przytoczony słownik, definiując wychowanie, w drugim znaczeniu określa je jako catoksztatt zabiegów majacych na celu uksztattowanie cztowieka pod względem fizycznym, moralnym i umystowym oraz przygotowanie go do życia w spoteczeństwie, dajacych mu wyksztatcenie w określonym kierunku ${ }^{8}$. Tym samym należy stwierdzić, że ty-

3 Por. np. N. Darwish, Okrucieństwo w majestacie prawa. Prześladowanie kobiet w świecie islamu, Warszawa 2011; Ibn Warraq, Dlaczego nie jestem muzutmaninem?, Warszawa 2013; R. Krawczyk, Islam jako system spoteczno-polityczny, Warszawa 2013.

4 Prof. Sakowicz, jak podaje notka o autorze, jest teologiem, religioznawcą, encyklopedystą-leksykografem, profesorem zwyczajnym na Uniwersytecie Kardynała Stefana Wyszyńskiego w Warszawie, kierownikiem Katedry Kultury i Edukacji Międzykulturowej na Wydziale Nauk Pedagogicznych UKSW, autorem szeregu prac na temat dialogu Kościoła katolickiego z islamem.

5 Instytucje edukacyjne Gülena sa obecne w wielu krajach, także w Polsce. W 1998 r. istniało ponad 300 szkół w 50 krajach, zaś w 2007 r. działało prawie 1000 różnego rodzaju szkół gülenowskich.

6 W 2012 r. zajmował 10 miejsce na tej liście, a w zestawieniu 2014/2015 był umieszczony na 14 pozycji. Por. http://themuslim500.com/the-top-50, 17 VII 2015.

7 Por. Uniwersalny stownik jezyka polskiego, t. 1, red. S. Dubisz, Warszawa 2003, s. 787.

8 Tamże, t. 4, s. 562. 
tuł omawianej pracy zawiera circulus in definiendo, zwłaszcza że autor nie dał własnej wykładni wzmiankowanych terminów9 ${ }^{9}$ a posłużył się jedynie wywodami swojego bohatera, który stwierdzil, że edukacja jest czymś różnym od nauczania. Większość ludzi potrafi uczyć, ale jedynie niewielu umie wychowywać, edukować. [...] liczni moga być nauczycielami, ale liczba wychowawców jest ograniczona ${ }^{10}$. Trudno powyższym sformułowaniom przyznać walor naukowości.

Innym, znacznie poważniejszym błędem ze strony autora jest brak wskazania metody, jaką zastosował w analizie „dzieła” swojego bohatera. W monografii nie ma słowa na temat metodologii, niezbędnej przecież w omówieniu i ocenie pedagogicznej teorii i praktyki stosowanych w instytucjach edukacyjnych tureckiego „filantropa”. Autor pracy nie zastosował ani elementów ilościowych, ani jakościowych, nie badał programów nauczania, nie rozmawiał ze studentami, nie uczestniczył w zajęciach, nie analizował dokumentów szkolnych ${ }^{11}$. Odnoszę wrażenie, że ograniczył się wyłącznie do cytatów z prac i broszur samego Gülena lub jego apologetów ${ }^{12}$, co uważam za istotny błąd metodologiczny. Brak jakiegokolwiek krytycyzmu charakteryzuje w zasadzie całą ocenianą publikację.

Zanim przejdę do dalszych uwag, chciałbym kilka słów poświecić tytułowemu bohaterowi rozprawy. W rozdziale I, który jest jednocześnie swoistym wprowadzeniem, Sakowicz opisuje jego życie i dzieło. Z przedstawionego opisu możemy się dowiedzieć, że Gülen jest pedagogiem, edukatorem, nauczycielem, wychowawca, chociaż nie posiada akademickiego wyksztatcenia z zakresu pedagogiki lub dyscyplin pedagogice pokrewnych ${ }^{13}$. Polski autor pisze, że jego bohater w ogóle nie posiada formalnego wykształcenia akademickiego ${ }^{14}$. W tym kontekście musi co najmniej zastanawiać opinia Sakowicza, zgodnie z którą jego bohater w swoich wypowiedziach nie ograniczał się jedynie do kwestii religijnych, ale mówił także o edukacji, nauce, darwinizmie, ekonomii i sprawiedliwości społecznej, zaś gtębia $i$ walor, czyli jakość jego wypowiedzi na tak różne tematy zrobity największe wrażenie na spoteczności akademickiej, zapewnity

9 Co znamienne, w podtytule autor również używa trzeciego podobnego pojęcia: „pedagogiczna”.

10 E. Sakowicz, Muzutmańska edukacja i wychowanie..., s. 146. Ideał nauczyciela, który jest realizowany w szkołach Gülena, przybiera poniższą postać: Autentyczni nauczyciele sieją czyste ziarna i strzega ich. Zajmuja się tym, co dobre i zdrowe, a przede wszystkim wprowadzaja dzieci w życie i prowadza je poprzez okoliczności, jakie napotkają na swej drodze, tamże.

11 Szeroko o tej materii por. T. Pilch, T. Bauman, Zasady badań pedagogicznych, Warszawa 2010, passim. W pracy Sakowicza nie występują zatem obserwacja, eksperyment, test, socjometria, ankieta, wywiad i rozmowa, analiza dokumentów, arkusze, dzienniki obserwacji.

12 Jedyną krytyczną pozycją na temat Gülena, jaką marginalnie wspomina w przypisie, jest praca K. Górak-Sosnowskiej, Muzutmańska kultura konsumpcyjna, Warszawa 2011. Wymieniona autorka jedynie wzmiankuje Gülena na s. 167-169.

13 E. Sakowicz, Muzutmańska edukacja i wychowanie..., s. 23. Pedagog, edukator, nauczyciel, wychowawca - kolejny przykład definiowania idem per idem.

14 Tamże, s. 25. Amerykański autor Erick Stakelbeck zauważył, że Gülen nie posiada w ogóle wyższego wykształacenia, por. E. Stakelbeck, The Gülen Movement. A New Islamic World Order?, [online] http://www.cbn.com/cbnnews/world/2011/May/The-Gülen-Movement-The-New-Islamic-World-Order, 15 VII 2015. 
mu jej uwage i szacunek ${ }^{15}$. Szkoda, że Sakowicz nie przytoczył żadnych źródeł do tej swojej tezy i nie wskazał kraju, w którym społeczność akademicka taką czcią otacza bohatera jego książki. Zwolennicy Gülena uważają go za nauczyciela islamu i dlatego obdarzyli go honorowym tytułem Hodża Efendi, który oznacza osobę powszechnie szanowaną. Jeszcze dobitnej określa Gülena jego zwolennik i zarazem uczeń Arhan Kardaş, który nie zawahał się nazwać swojego mistrza słowami: „Jego Świątobliwość Fethullah Gülen"16. W podobnym tonie opisuje postać Gülena Sakowicz, który stwierdzil, że jest to wybitny intelektualista, opatrznościowy mąż boży, działający dla dobra innych. Nazywa go nawet „charyzmatykiem islamu”. Dalej bezkrytycznie przytacza następującą opinię: O tureckim pedagogu mówi się też jak o tym, który prawie w ogóle nie udaje się na spoczynek nocny, gdyż caty jego czas zabiera troska o dobro ludzkości. Zastrzega jednak, że trudno weryfikować tę opinię, i dodaje od siebie: Nie ulega natomiast wątpliwości, iż cztowiek stużacy innym ludziom, oddany catkowicie sprawie cztowieka, nie liczy swojego czasu. Nie mierzy go, nie wydziela innym, lecz caty jest dla nich, dla idei, która stuży poprawie jakości życia oraz stanowi dar dla ludzkości. Osoba taka wtaściwie nie ma czasu dla siebie. Każda chwila jej życia stanowi jej dar dla drugiego ${ }^{17}$. Myślę, że ten długi cytat nie potrzebuje komentarza. Co znamienne, tego typu spostrzeżenia przewijają się przez całą treść książki. Jak wskazuje polski badacz, Hodża Efendi w 1998 r. udał się na dobrowolną emigrację do USA i osiadł w Saylorsburgu w Pensylwanii, gdzie stworzył i kieruje Golden Generation Worship and Retreat Center (Centrum Kultu i Ucieczki Złotego Pokolenia) - cokolwiek ta nazwa oznacza. Polski biograf nie wyjawia prawdziwych powodów opuszczenia Turcji przez Gülena. Warto wiedzieć, że szkoły założone przez Efendiego w USA znajdują się w niemal każdym stanie i noszą specyficzne nazwy: Magnoliowa Akademia Nauki, Akademia Horyzontów Nauki, Szkoła Społeczna Pionierów, Szlachetna Akademia czy Gołębia Akademia Nauki ${ }^{18}$.

Sakowicz jedynie marginalnie odnosi się do krytycznych uwag na temat Gülena poczynionych przez Katarzynę Górak-Sosnowską, która nie zawahała się stwierdzić, że kierowany przez niego ruch działa na dwóch poziomach: tajnej organizacji, do której należą najbardziej wpływowi członkowie ruchu, po przejściu szeregu stopni wtajemniczenia, oraz na poziomie jawnym, obejmującym zewnętrzne przejawy działalności (działalność wydawnicza, edukacyjna itp.). Autorka ta konstatuje, że nieprzejrzysta struktura oraz ogromne wpływy i fortuna Gülena powodują, iż podejmowane przez niego działania oceniane są jako mocno podejrzane. Pojawiają się zarzuty, że dzięki sieci instytucji edukacyjnych (szkoły, uniwersytety) może on kontrolować przyszłą elitę intelektualną w krajach, w których działają firmowane przez niego instytucje. Jak

\footnotetext{
E. Sakowicz, Muzutmańska edukacja i wychowanie..., s. 24.
}

16 Tamże. W tym samym duchu inna zwolenniczka Gülena, która nie zawahała się, chyba nieco na wyrost, swojego szkicu o nim zatytułować: Gülen, Konfucjusz i Platon o edukacji, por. tamże, s. 114.

17 Tami̇e, s. 27.

18 Por. P.L. Williams, FBI Launches Investigation of Gülen and His Movement, [online] http://canadafreepress.com/article/34766, 1 VII 2015. 
zauważa Górak-Sosnowska, większosśc szkół zakładanych przez Gülena to szkoły dla chłopców, a ich założyciel często oskarżany jest o fundamentalizm. W kwestiach teologicznych zajmuje on stanowisko konserwatywne, typowe dla głównego nurtu islamu sunnickiego. Zaś czytelnicy jego prac mogą szukać w nich „ukojenia ducha”, ale nie rozwiązania rzeczywistych problemów codziennego życia ${ }^{19}$.

Jeszcze ostrzejsze krytyczne uwagi na temat Gülena i stworzonego przez niego ruchu znaleźć można u innych autorów. Erick Stakelbeck przekonuje, że Gülen to wilk w owczej skórze, współczesny Chomeini, który pragnie zaprowadzić nowy islamski $\mathfrak{ł a d}^{20}$. Chociaż sam Gülen dowodzi, że reprezentuje umiarkowany islam, dążący do porozumienia z otaczającym go światem poprzez dialog międzywyznaniowy i naukę, to jednak Ariel Cohen, ekspert ds. Bliskiego Wschodu w Heritage Foundation, uważa, że kwestia ta jest znacznie bardziej złożona. Ruch zapoczątkowany przez Gülena nie jest wyłącznie ruchem religijnym, jest to Ruch Fethullaha Gülena - jego członkowie sami używają tej nazwy. Cohen, który wnikliwie badał tę formację, uważa, że koncepcja świata proponowana przez Gülena jest zgodna z islamem, jednak nie chodzi w niej o kalifat czy państwo funkcjonujące w oparciu o prawo szariatu, ale, i tak określa te dążenia sam twórca ruchu, o „Nowy Islamski Ład Światowy” ${ }^{21}$. Jeszcze bardziej zdecydowanie wypowiedział się francusko-turecki badacz Bayram Balci, w ocenie którego ruch dąży do osiągnięcia trzech celów: islamizacji nacjonalistycznej ideologii Turcji, „turcyfikacji” islamu i islamizacji współczesności ${ }^{22}$.

Paul L. Williams uważa, że Gülen uciekł z Turcji w 1998 r., ponieważ oskarżono go o zamiar obalenia świeckich władz tego państwa. Aktualnie mieszka w dużej posiadłości w górach Pocono w stanie Pensylwania. Zgodnie z danymi sądu zgromadzony przez niego majątek szacowany jest na 25 mld dolarów ${ }^{23}$. W 2011 r. prowadzone było przeciwko niemu śledztwo federalne, które koncentrowało się na oskarżeniu, zgodnie z którym pracownicy szkół społecznych założonych przez Gülena byli zobowiązani do przekazywania darowizny w wysokości $60 \%$ zarobków na rzecz Ruchu Gülena. Zwolennicy Gülena przekonywali, że te pieniądze miały być wydawane na zakładanie nowych szkół, jednakże placówki te są w całości finansowane z pieniędzy podatników. Warto wiedzieć, że sama tylko Akademia Nauki Truebright (należy do sieci szkół Gülena) uzyskuje na swoich 348 uczniów roczną dotację w wysokości $3 \mathrm{mln}$ dolarów od Filadelfijskiego Okręgu Szkolnego ${ }^{24}$. Wobec powyższego nie

19 K. Górak-Sosnowska, Muzutmańska..., s. 168-169.

20 E. Stakelbeck, The Gülen Movement...

21 Tamże.

22 Tamże. Gwoli prawdy należy dodać, że Sakowicz wzmiankuje o tych zastrzeżeniach, por. E. Sakowicz, Muzutmańska edukacja i wychowanie..., s. 25.

23 P.L. Williams, FBI Launches Investigation...

24 Por. M. Woodall, C. Gatti, [online] http://articles.philly.com/2011-03-20/news/29148147_1_ Gülen-schools-Gülen-followers-charter-schools, 25 VI 2015. Co ciekawe, podejrzenia agentów wzbudziła także liczba wiz H1B wydanych pracownikom Gülena. Wizy te otrzymują cudzoziemcy, specjaliści na polu matematyki, fizyki i technologii, którzy są w stanie wypełnić luki na amerykańskim rynku pracy. W 2009 r. rząd wydał szkołom Gülena 684 wizy H1B; dla porównania - firma Google otrzy- 
do utrzymania jest teza Sakowicza, że finansowanie szkół gülenowskich jest w pełni transparentne $e^{25}$.

Brytyjski „The Telegraph” w lutym 2015 r. zauważył, że oskarżenia Gülena o próby zaprowadzenia w Turcji społeczeństwa równoległego doprowadziły do zerwania sojuszu tureckiego miliardera z partią Sprawiedliwości i Rozwoju (AKP) kierowaną przez wieloletniego premiera, a obecnie prezydenta Turcji Recepa Tayyipa Erdoğana ${ }^{26}$. Jak wskazuje autorka tekstu, wcześniej byli oni sojusznikami, ale od 2013 r. rozłam pomiędzy kaznodzieją Fethullahem Gülenem i tureckim prezydentem Erdoğanem stale się pogłębia ${ }^{27}$. Przedstawione powyżej fakty i opinie na temat Gülena pozwalają postawić tezę, że podejmowane przez niego działania nie przez wszystkich oceniane są z taką aprobatą, jak chciałby jego polski biograf ${ }^{28}$. Tych krytycznych wypowiedzi na temat Hodży Efendiego próżno szukać w jego pracy.

Już we wstępie Sakowicz stwierdza (wbrew tytułowi), że jego praca nie będzie dotyczyła pedagogiki, lecz przedmiotem jej zainteresowania będzie edukacja i wychowanie według islamu ${ }^{29}$. Taka deklaracja pozwala założyć, że jej autor ma sporą wiedzę na temat tej religii i nie będzie stronił od merytorycznych odniesień w tej materii. Rzeczywiście, w recenzowanej pracy znaleźć można wiele uwag poczynionych przez jej autora na temat islamu. Niestety są one najczęściej błędne.

Na pierwszy istotny błąd merytoryczny można natknąć się już na stronie 16, gdzie Sakowicz dokonuje zrównania islamu z chrześcijaństwem, przekonując, że Allah, podobne jak Bóg chrześcijan, swoimi dobrodziejstwami obdarowuje nie tylko muzułmanów. Jest to zupełnie fałszywe stwierdzenie, albowiem Koran w surze III w ajacie 85 stanowi wprost, że tylko muzułmanie trafią do raju: A od tego, kto poszukuje innej religii niż islam, nie będzie ona przyjęta; i on w życiu ostatecznym będzie w liczbie tych, którzy ponieśli stratę $e^{30}$. Podobnie w wielu innych miejscach. Dla przykładu wskażę następujące słowa: Zaprawdę, nad tymi, którzy nie uwierzyli i umarli, będą niewiernymi - nad nimi przekleństwo Boga, aniotów i ludzi, wszystkich razem! Będzie im ono towarzyszyćna

mała ich tylko 440, tamże. Przywołany artykuł przytacza jeszcze więcej różnego rodzaju zarzutów pod adresem szkół Gülena w USA.

25 E. Sakowicz, Muzutmańska edukacja i wychowanie..., s. 159-160.

26 Por. R. Akkoc, A Parallel State within Turkey? How the Country's Democracy Came under Attack from Two Men's Rivalry, [online] http://www.telegraph.co.uk/news/worldnews/europe/turkey/ 11397876/A-parallel-state-within-Turkey-How-the-countrys-democracy-came-under-attack-from-two-mens-rivalry.html, 15 VI 2015.

Tamże. Tam też szersze tło konfliktu pomiędzy Gülenem i Erdoğanem.

28 Na temat działności i ambicji Gülena i jego ruchu por. też: R. Sharon-Krespin, Fethullah Gülen's Grand Ambition. Turkey's Islamist Danger, [online] http://www.meforum.org/2045/fethullah-Gülens -grand-ambition, 15 V 2015. Przytoczone opracowanie zostało opublikowane w $2009 \mathrm{r}$.

E. Sakowicz, Muzutmańska edukacja i wychowanie..., s. 17.

Wszystkie cytaty z Koranu przytaczam za: Koran, przeł. i koment. J. Bielawski, Warszawa 1986. Cyfra rzymska oznacza surę (rozdział Koranu), a arabska ajat (werset). W kwestii różnic teologicznych pomiędzy chrześcijaństwem a islamem por. dla przykładu J. Nosowski, Teologia Koranu. Wyktad systematyczny, Warszawa 1970, passim. 
wieki. I kara ich nie będzie zmniejszona, i nie uzyskają żadnej zwtoki ${ }^{31}$. Należy pamiętać, że islam odrzucił doktrynalne podstawy chrześcijaństwa: boskość Chrystusa, Trójcę Świętą, wcielenie, ukrzyżowanie i odkupienie ${ }^{32}$. Wyznawcy islamu są przekonani, że ich religia jest najlepsza, stanowi bowiem dopełnienie poprzednich monoteizmów: judaizmu i chrześcijaństwa, które nie mogą się z nią równać. Sam Koran potwierdza pierwszeństwo islamu i jego wyznawców w stosunku do innych religii. Swoje przekonanie muzułmanie wyprowadzają z następujących słów: Wy jesteście najlepszym narodem, jaki zostat stworzony dla ludzi: wy nakazujecie to, co jest uznane, a zakazujecie tego, co jest naganne; i wierzycie w Boga. A jeśliby uwierzyt lud Ksiegi, to bytoby dla niego lepiej. W'ród nich sa wierzacy, lecz większość z nich to ludzie szerzacy zepsucię3.

Wspomniane zrównanie chrześcijan i muzułmanów jest błędne nie tylko na gruncie teologicznym, ale zwłaszcza prawnym. W krajach muzułmańskich (np. Arabia Saudyjska, Pakistan, Iran) ludzie są klasyfikowani nie tylko według płci, ale także przynależności religijnej. W wielu krajach muzułmańskich, niezależnie od ich formy ustrojowej, głowa państwa musi być muzułmaninem, którego oboje rodzice również byli wyznawcami islamu ${ }^{34}$. W społeczeństwie muzułmańskim istnieją cztery zasadnicze grupy, które posiadają odmienny status prawny: muzułmanie - tylko oni są pełnoprawnymi obywatelami, a swoją pozycję uzyskują poprzez urodzenie lub konwersję; wyznawcy religii monoteistycznych, do których należą żydzi, chrześcijanie oraz samarytanie i sabejczycy; wyznawcy religii politeistycznych lub nieuznawanych przez islam, np. bahaici, podobny status prawny mają ateiści; i apostaci, to znaczy muzułmanie, którzy odeszli od islamu, dołączając do jednej z wymienionych grup. Apostaci są w najmniej korzystnej sytuacji, ponieważ przeciw nim skierowane są szczególne sankcje prawne.

Prawo islamu bazuje zatem na trzech fundamentalnych nierównościach: pomiędzy muzułmaninem a niemuzułmaninem, pomiędzy mężczyzną a kobietą oraz pomiędzy wolnym a niewolnikiem (dziś to trzecie rozróżnienie straciło na znaczeniu). Z punktu widzenia prawnego szariat uznaje wyższość muzułmanina nad niemuzułmaninem, podobnie jak wyższość mężczyzny nad kobietą. Kobiety mają niższy status, którego źródeł poszukiwać należy już w Koranie - sura II werset 228 głosi: Mężczyźni maja nad nimi wyższość. Dla przykładu wskażę następujące różnice: tylko muzułmanin mężczyzna może poślubić niemuzułmankę, mężczyzna może mieć cztery żony, ale kobieta nie może mieć kilku mężów, zeznania jednego mężczyzny równoważą zeznania dwóch kobiet, muzułmanka nie może poślubić niemuzułmanina, kobieta dziedziczy połowę tego, co mężczyzna. Niemuzułmanin nie może dziedziczyć po muzułmaninie. Przytoczone powyżej stanowiska pozwalają uznać za kompletnie fałszywą tezę Gülena dowodzącą, że islam gtosi równość wszystkich ludzi i dlatego kooperacja zamożnych i ubogich nie

\footnotetext{
31 Por. Koran, II-161-162.

32 Por. G. Paolucci, C. Eid, Islam. Sto pytań. Odpowiada Samir Khalil Samir, przeł. K. Klauza, Warszawa 2004, s. 126-127.

33 Koran, III-110.

34 Szerzej na ten temat por. Z. Landowski, Polityczny wymiar islamu we wspótczesnych konstytucjach, Warszawa 2013, s. 185-189.
} 
tylko jest możliwa, ale i konieczna ${ }^{35}$. Podobnie zresztą jak poniższe stwierdzenie: Upodstaw muzutmańskiej edukacji leży przekonanie, iż każdy cztowiek jest istota godna szacun$k u$ oraz $c z c i^{36}$. Gdyby powyższa teza była zgodna z szariatem, nawet apostaci mogliby się czuć bezpieczni w krajach muzułmańskich, niestety odejście od islamu w wielu z nich ciągle karane jest śmiercią.

Jak zauważył Henri Teissier, teoria bardzo często odbiega od praktyki, albowiem współcześnie niewiele jest oficjalnych aktów prawnych, które ograniczałyby prawa obywatelskie chrześcijan w większości państw muzułmańskich. W niektórych jednak chrześcijanin nie może zostać głową państwa, nauczać w szkołach arabskiego, ponieważ jest to język Koranu. Jednakże znacznie gorsze od formalnych nierówności prawnych jest psychologiczne spychanie na margines przejawiające się na wiele sposobów, które pokazuje niemuzułmanom, że są obywatelami drugiej kategorii ${ }^{37}$.

Inną, co najmniej dyskusyjną tezą, jaką bezkrytycznie przytacza Sakowicz, jest fragment oświadczenia Gülena po zamachach na USA w 2001 r. Turecki Efendi stwierdził $\mathrm{w}$ nim, że terror nie może być nigdy stosowany w imię islamu lub dla osiagnięcia jakichkolwiek celów islamskich. Terrorysta nie może być muzutmaninem, a muzutmanin nie może być terrorysta. Muzutmaninowi wolno byćjedynie przedstawicielem i symbolem pokoju, dobrobytu oraz pomyślności $i^{38}$. Uważam, że przytoczonej wypowiedzi nie wolno pozostawić bez komentarza, albowiem prezentuje ona osobiste stanowisko jej autora i nie jest reprezentatywna dla ogółu muzułmanów. Islam sunnicki formalnie nie uznaje hierarchii religijnej, nie ma zatem powszechnie uznawanego autorytetu, którego wypowiedzi byłyby wiążące dla ogółu wiernych. Znamiennym przykładem pozwalającym interpretować Koran w duchu pokoju lub walki jest kwestia dżihadu ${ }^{39}$, który może być rozumiany w sensie pokojowym lub jako nieustanna wojna z niewiernymi. Co znamienne, z powodu braku wspomnianego powszechnego autorytetu obie interpretacje są uprawnione na gruncie metodologicznym. Także muzułmańscy terroryści przekonują, że ich działalność opiera się na wartościach islamu, a dżihad jest uprawnioną formą działania, której głównym celem jest zaprowadzenie islamskiego porządku opartego na szariacie. Ataki terrorystyczne mają być wymierzone tak samo w wojskowych, jak i w cywilów, ich celem jest w szczególności każdy Amerykanin oraz każdy jego sojusznik. Taki właśnie nakaz religijny wydano w 1998 r. podczas posiedzenia Światowego Frontu Islamskiego. Jego uczestnicy podzielali przekonanie, że im większa liczba ofiar, tym większa chwała dla Allaha ${ }^{40}$. Również wielu muzułmańskich imamów, np. w Wielkiej Brytanii, Francji, Hiszpanii, Włoszech czy Niemczech, opowiada się za dżihadem pojmowanym

35 E. Sakowicz, Muzutmańska edukacja i wychowanie..., s. 167.

36 Tamże, s. 73.

37 Por. H. Teissier, Chrześcijanin wobec islamu, [w:] E. Sakowicz, Czy islam jest religia terrorystów?, Kraków 2002, s. 158.

38 E. Sakowicz, Muzutmańska edukacja i wychowanie..., s. 39.

39 Szerzej na ten temat por. M. Sadowski, Dżihad - święta wojna w islamie?, „Przegląd Bezpieczeństwa Wewnętrznego" 2013, nr 8(5), s. 29-47.

40 I. Witkowski, Supertajne bronie islamu, Warszawa 1999, s. 98. 
jako zbrojna walka z niewiernymi ${ }^{41}$. Warto mieć też na uwadze, że zamachy terrorystyczne przeprowadzone przez odwołujących się do islamu sprawców rzadko spotykały się z potępieniem przez współwyznawców zamieszkujących kraje islamskie. Niekiedy nawet zabójców uznawano za bohaterów. W pogrzebie dwudziestodwuletniego Shahzada Tanweera (urodzonego w Bradford w Anglii zamachowca z Londynu w 2005 r.) uczestniczyły w Pakistanie dziesiątki tysięcy ludzi, dla których był on szahidem - męczennikiem za wiarę.

W tym miejscu warto przypomnieć w kilku słowach poglądy jednego z mistrzów ideowych Gülena, średniowiecznego mistyka muzułmańskiego Al-Ghazalego ${ }^{42}$. Ten myśliciel był nie tylko odnowicielem życia religijnego w islamie, ale również zwolennikiem nieustannego dżihadu, wzywał bowiem wiernych do udziału w dżihadzie przynajmniej raz w roku, mając na myśli walkę z niewiernymi. Głosił: [...] każdy musi wzią́ udziat w dżihadzieprzynajmniej raz do roku [...] Wolno użyćkatapultyprzeciw nim [niemuzułmanom - przyp. M.S.], kiedy sq w fortecy, nawet jeśli sq wśród nich kobiety i dzieci. Wolno ich podpalić i/lub utopic ${ }^{43}$. Przytoczona wypowiedź Al-Ghazalego dowodzi zatem wyraźnie, że poglądy przynajmniej niektórych autorów, z jakich czerpie inspiracje Gülen, nie zawsze mają jednoznacznie pokojowy i tolerancyjny charakter.

Istotną nieścisłość znaleźć można w stwierdzeniu polskiego religioznawcy, kiedy głosi, że zemsta nigdy nie miata $w$ islamie charakteru powszechnego ${ }^{44}$. Uważam, że jest to całkowicie błędna konstatacja. Prawo karne islamu także współcześnie przewiduje możliwość stosowania odpłaty - kisas. Nie wchodząc w zbędne szczegóły, przypomnę, że odpowiedzialność za przestępstwo z kategorii kisas oparta jest na zasadach sprawiedliwej odpłaty (talionu), zaś zalicza się do niej zabójstwo i uszkodzenie ciała. Kary, które przewidziane są za te czyny, są określone w Koranie, w związku z czym nie mogą podlegać żadnym dyskusjom. Ponieważ naruszają prawo jednostki, to od woli pokrzywdzonego (lub jego rodziny w przypadku zabójstwa) zależy, czy sprawcy zostanie wymierzona kara w postaci kisas, czy też odwet zostanie zastąpiony przez zadośćuczynienie ofierze lub jej rodzinie ${ }^{45}$. Instytucja odpłaty nie jest przepisem martwym, a współcześnie funkcjonuje np. w Arabii Saudyjskiej. W tym kraju rodzina osoby za-

41 Jako przykład można tu wskazać słynnego szejka Yousufa al-Qaradawiego oraz imamów Abu Hamzę i Abu Katadę z Wielkiej Brytanii, imama Alego Ibrahima El Soudany, Egipcjanina deportowanego z Francji do swego rodzinnego kraju za „apologię dżihadu”, oraz hiszpańskiego imama meczetu w Léridzie Abdelwahaba Houziego, a także wielu innych.

42 Abu Hamid Muhammad Al-Ghazali (1058-1111) był teologiem, filozofem, mistykiem, prawnikiem i muzułmańskim teoretykiem polityki. W myśl jego koncepcji politycznej szariat jest fundamentem, na którym opiera się funkcjonowanie państwa bożego. W swoich rozważaniach podejmował kwestie jedności władzy duchownej i świeckiej, przekonywał, że rządy w państwie powinny być tak sprawowane, aby wierny muzułmanin mógł jak najlepiej przygotować się do życia przyszłego. Al-Ghazali jest uważany przez muzułmanów za drugi po proroku Mahomecie wielki autorytet islamu. Angelo Scarabel twierdzi, że synteza islamu, jakiej dokonał Al-Ghazali, może być uznana za summa theologiae islamu. Por. A. Scarabel, Islam, przeł. K. Stopa, Kraków 2004, s. 53.

43 Za: M.A. Khan, Islamic Jihad. A Legacy of Forced Conversion, Imperialism and Slavery, New York 2009, s. 1.

44 E. Sakowicz, Muzutmańska edukacja i wychowanie..., s. 54.

45 Szeroko w tej materii por. J. Bury, J. Kasprzak, Prawo karne islamu, Warszawa 2007, s. 121 i nast. 
bitej, również nieumyślnie, może żądać śmierci sprawcy. Nawet sam król Arabii Saudyjskiej ma w tej sytuacji ograniczone możliwości działania, zmierzające do tego, aby uprawniony zrezygnował $z$ odwetu i przyjął zadośćuczynienie finansowe ${ }^{46}$.

Inny błąd merytoryczny polega na bezdyskusyjnym przytoczeniu przez Sakowicza poglądu, zgodnie z którym Mahomet był analfabetą, który usłyszał stowo Boga i wiernie je inlibrowat (uksiazikowit). Stowo Allaha, przyjęte przez analfabete, byto wolne od jakiejkolwiek ludzkiej korekty. Okazato sie czystym, jasnym, niezafatszowanym stowem - Koranem, księgq wieczna, mająca swój wzór w niebie $e^{47}$. Odniosę się tutaj jedynie do rzekomego analfabetyzmu Mahometa ${ }^{48}$, wiadomo bowiem, że pogląd ten został już zakwestionowany, zarówno w przeszłości, jak i współcześnie. Dla przykładu wskażę poglądy Charlesa Torreya, który już w latach 30. ubiegłego stulecia z przekonaniem wywodzil, że Mahomet potrafił czytać i pisać. Przemawiało za tym jego pochodzenie społeczne, jest bowiem mało prawdopodobne, że nie otrzymał on żadnego wykształcenia. Należy również pamiętać, że zawsze, kiedy Koran mówi o ummi (analfabecie), przeciwstawia to pojęcie słowom określającym tych, którzy posiadają Świętą Księgę. Zatem pojęcie to (w liczbie mnogiej - ummijun) odnosi się nie do tych, którzy nie potrafią czytać, lecz zapewne do tych, którzy nie posiadają objawionej Księgi. Frazę głoszącą, że Mahomet jest prorokiem dla analfabetów, należy tłumaczyć w ten sposób, że jest on prorokiem posłanym do pogan, z wyłączeniem żydów i chrześcijan, albowiem wymienieni mają już swoje święte księgi ${ }^{49}$. Wydaje się także mało prawdopodobne, że człowiek, który kierował karawanami kupieckimi, a do tej roli wynajęła go najpierw Chadidża, nie potrafił pisać ani czytać.

Równie krytycznie należy ocenić bezrefleksyjne przytaczanie przez polskiego biografa opinii Hodży Efendiego głoszącej, że szkoła Mahometa wydała sprawiedliwych władców, do których Sakowicz zaliczył Abu Bakra, Usmana, Umara i Alego ${ }^{50}$. Należy przypomnieć, że z wymienionej czwórki tylko Abu Bakr zmarł śmiercią naturalną. Pozostali zostali zamordowani przez swoich przeciwników politycznych, z którymi toczyli nieustanne walki.

Zastanawiającym faktem jest przywołanie przez Eugeniusza Sakowicza autorytetu św. Tomasza z Akwinu w kontekście podkreślenia wkładu tego myśliciela w poznanie filozofii islamu w Europie ${ }^{51}$. Czyżby polski biograf Hodży Efendiego nie znał jego poglądów zawartych w Sumie przeciwko poganom i chciał dla poparcia swoich tez wykorzystać jego autorytet? Akwinata we wspomnianym dziele stwierdził dobitnie:

Ci zaś, którzy wprowadzili btędy sekciarskie, postępowali droga przeciwna, jak to widać u Mahometa; zwabiat on ludy obietnicami rozkoszy zmystowych, do których pragnienia

46 Por. Q. Ahmed, W kraju niewidzialnych kobiet, przeł. E. Krawczyk, Warszawa 2013, s. 303-311.

47 E. Sakowicz, Muzutmańska edukacja i wychowanie..., s. 63-64.

48 Odnośnie do nieomylności, cudowności Kranu por. Raszida Al-Maghribiego (byłego muzułmanina, nawróconego na chrześcijaństwo) Czy Koran jest stowem Bożym? Świadectwo nawrócenia muzutmanina, Poznań 2011, passim.

49 C.C. Torrey, The Jewish Foundation of Islam, New York 1933, s. 36-42. Tam też szersze rozważania w tej materii. W tym samym duchu tłumaczył rzekomy analfabetyzm Mahometa Samir Khalil Samir, por. Por. G. Paolucci, C. Eid, Islam. Sto pytań..., s. 22-23.

50 E. Sakowicz, Muzutmańska edukacja i wychowanie..., s. 68.

51 Tamże, s. 111. 
podnieca pożądliwość ciata. Mahomet podawat także przykazania odpowiednie do obietnic, popuszczajac cugli pożadliwości cielesnej, a temu ludzie zmystowi tatwy dają postuch. Jako dowody prawdy zaś podawat tylko takie, które każdy średnio madry cztowiek może poznać rozumem przyrodzonym. Co więcej, prawdy, których nauczat, pomieszat z wieloma bajkami i zupetnie btędnymi naukami. [...] Poza tym ci, którzy uwierzyli z początku Mahometowi, nie byli jakimiś uczonymi, wyksztatconymi w sprawach boskich i ludzkich, lecz byli to ludzie dzicy, przebywajacy na pustyniach i nie znajacy żadnej nauki boskiej. Wykorzystujac ttum takich ludzi i przemoc zbrojna, zmusit innych do poddania sie jego prawu. [...] I tak widać, że ci, którzy daja wiare jego stowom, wierza lekkomyślnie ${ }^{52}$.

Przytoczone powyżej poglądy są bardzo krytyczne zarówno wobec islamu, jak i jego proroka.

Polski autor przywołuje też autorytet Jana Pawła II - Gülen uczestniczył w jednym ze spotkań z papieżem w 1998 r. Dla aprobaty poglądów swojego bohatera pominął jednak poniższe spostrzeżenie papieża Polaka: chociaż Bóg Koranu nazwany jest najpiękniejszymi imionami, jakie zna ludzki język, [to] ostatecznie jest to pozaświatowy Bóg, który pozostaje tylko Majestatem, a nie jest nigdy Emanuelem, Bogiem z Nami. Islam nie jest religia odkupienia [...] Dlatego nie tylko teologia, ale także i antropologia islamu tak bardzo różni się od antropologii chrześcijańskiej 53 .

Trudne do zaakceptowania w pracy naukowej są poniższe stwierdzenia Sakowicza: Gülen wiele uwagi poświęca specyfice edukacji kobiet, przypomniał bowiem zasadę: by dziewczynki wychowywać na istoty delikatne jak kwiaty, które powinny być kształtowane na tagodnych i uczuciowych wychowawców dzieci $i^{54}$. Przywoływanie w kontekście edukacji, zwłaszcza edukacji kobiet, jako autorytetu czwartego kalifa prawowiernego Alego ibn Abu Taliba wydaje się co najmniej zastanawiające, ponieważ znany jest jego hadis, w którym na widok mężczyzny uczącego kobietę pisać stwierdził: Nie dodawaj zta do nieszczęścia ${ }^{55}$. Bardzo zachowawcze stanowisko wobec kobiet zajmował również inny autorytet przywoływany przez Gülena, Al-Ghazali. W jednym ze swoich dzieł w następujący sposób określa on rolę kobiety: Powinna siedzieć $w$ domu i przaśśc, nie powinna za czesto wychodzić, nie wolno jej za wiele wiedzieć ani rozmawiać z sasiadami. Powinna dbać o swojego męża. Powinna próbować zadowalać go na wszelkie możliwe sposoby ${ }^{56}$.

Zupełnie nie do przyjęcia są fragmenty dotyczące kwestii szariatu i istoty islamu. Bez żadnego komentarza polski autor pozostawia następujące wypowiedzi swojego bohatera: islam to religia, a nie program polityczny czy konstytucja. 95\% regulacji prawa koranicznego jest natury osobistej i nie wymaga aparatu urzędniczego ${ }^{57}$. Powyższa konstatacja jest błędna. Analizując szariat (prawo islamu, prawo muzułmańskie - pojęcia

52 Św. Tomasz z Akwinu, Summa contra gentiles. Prawdy wiary chrześcijańskiej w dyskusji z poganami, innowiercami i btądzącymi, t. 1, Poznań 2003, ks. I, rozdz. 6.

53 Güleneł II, Lublin 1994, s. 82.

54 E. Sakowicz, Muzutmańska edukacja i wychowanie..., s. 110-111.

55 Przytaczam za: Ibn Warraq, Dlaczego nie jestem muzutmaninem?, s. 394.

56 Przytaczam za: tamże, s. 394.

57 E. Sakowicz, Muzutmańska edukacja i wychowanie..., s. 131. 
tożsame), ciągle trzeba pamiętać o tym, że prawo islamu to nie tylko system sądowniczy i doktryna prawna, której zadaniem było regulowanie stosunków społecznych i rozwiązywania sporów, ale także dyskursywne praktyki, które strukturalnie i organicznie powiązane były z otaczającym je światem. Prawo islamu reguluje kwestie gospodarcze i społeczne, moralne i etyczne, intelektualne i duchowe, poznawcze i kulturowe, literackie i jeszcze szereg innych ${ }^{58}$. Należy również stale mieć na uwadze, że islam to nie tylko religia, ale że jest to przede wszystkim system społeczno-polityczny, a nawet wszechobejmująca ideologia. Te same pojęcia są wykorzystywane tak w prawnym, jak i w religijnym rozumieniu, rozpatrywane bądź jako składniki religijnego, bądź prawnego systemu, bądź też włącza się je równocześnie w skład obu systemów. W konsekwencji $\mathrm{w}$ islamie praktycznie niemożliwa jest wyraźna dystynkcja pomiędzy teologami a jurystami. Swoiste zrównanie teologii i jurysprudencji doprowadziło do sytuacji, w której islamu pojmowanemu jako religia i kultura nie sposób zrozumieć bez znajomości islamskiego systemu prawnego ${ }^{59}$. Ponadto należy pamiętać, że Koran zawiera jedynie skromną część szariatu, zdecydowana większość jego norm znajduje się zaś w sunnie - tradycji proroka Mahometa. Jego stanowisko tam przytoczone bywa niekiedy znacznie bardziej restrykcyjne niż treści zawarte w Koranie, a regulujące tę samą kwestię ${ }^{60}$.

Trudno się również zgodzić z tezą Sakowicza, że strach Europejczyków przed szariatem wynika nie tylko z niewiedzy o islamie, ale głównie z ignorancji religijnej ${ }^{61}$. W moim przekonaniu ten lęk jest w pełni uzasadniony, zwłaszcza dziś, kiedy tak surowe i restrykcyjne prawo islamu pragnie objąć swoim zasięgiem również niemuzułmanów, nawet tych, którzy żyją w państwach Europy Zachodniej. Wskazany wcześniej brak podziału na sacrum i profanum musi budzić niepokój, ponieważ w islamie model edukacji służyć ma przede wszystkim rozwojowi tej religii i z tego powodu może być łatwo wykorzystany do wprowadzenia w życie określonej doktryny politycznej - np. dżihadyzmu ${ }^{62}$. Tym samym mało prawdopodobne jest, aby system dążący do totalnej regulacji wszystkich sfer życia pozwolił na niezależną od niego działalność pedagogiczną.

Ostatnia kwestia, jaką chciałbym poruszyć, dotyczy spraw związanych wprost z edukacją prowadzoną w szkołach Ruchu Gülena. Mój wywód będzie tutaj oparty wyłącznie na źródłach pośrednich, albowiem, jak zaznaczyłem już wcześniej, Sakowicz nie wskazał żadnego przykładu w tej kwestii. Jak deklaruje turecki miliarder, celem nauki jest uczynie-

58 W.B. Hallaq, What is Sharia?, „Yearbook of Islamic and Middle Eastern Law” 2005-2006, Vol. 12, s. 156.

59 M. Hoffman, Islam jako alternatywa, [online] http://www.ipdirect.home.pl/kmp/publication/islam_jako_alternatywa/16\%20islam\%20jako\%20alternatywa\%20islamska\%20jurysprudencja.htm, 15 IX 2013.

60 Dla przykładu wskażę kwestię kary za cudzołóstwo. Pomimo że w Koranie karą za cudzołóstwo jest sto batów, zarówno dla cudzołożnika, jak i cudzołożnicy, to zgodnie z szariatem - tak nakazał w jednym z hadisów sam Mahomet - karą za to przestępstwo jest śmierć poprzez ukamienowanie. Por. M. Sadowski, Naskh - metoda usuwania sprzeczności w prawie islamu, Wrocław 2014, s. 70, Wroctawskie Studia Erazmiańskie, z. 8.

61 E. Sakowicz, Muzutmańska edukacja i wychowanie..., s. 132.

${ }^{62}$ Odnośnie do dżihadyzmu por. szerzej G. Weigel, Wiara, rozum i wojna z dżihadyzmem, Warszawa 2009, passim. 
nie z wiedzy przewodnika przez życie oraz oświetlenie drogi do poprawy ludzkoścíi ${ }^{63}$.Zaiste, powyższy program jest niezwykle ambitny, ale równie mało konkretny. W podobnym duchu sformułowano kryteria dobrej edukacji: harmonijnie ksztattuje, rozwija, oraz - jak trzeba - koryguje wszystkie sfery cztowieka; intelektualna, wolitywna oraz emocjonalna. Sakowicz podkreśla, że szkota w pewnym sensie spetnia postannictwo islamu jako religii, a na poparcie tej tezy przytacza słowa swojego bohatera: islam, droga pośrednia pomiędzy wszystkimi skrajnościami, zwraca się do wszystkich ludzkich zdolności i zmystów, a także do umystu każdej jednostki, jej serca i uczuć. Obejmuje każdy aspekt ludzkiego życia. To dlatego Prorok Muhammad zwracat szczególną uwagę na naukę, handel, rolnictwo, dziatanie i myślenie ${ }^{64}$. Nie jest łatwo polemizować z tego typu „naukowymi” spostrzeżeniami.

Eugeniusz Sakowicz wielokrotnie podkreślał, że nauczanie w szkołach Gülena stoi na bardzo wysokim poziomie, zarówno w przypadku nauk humanistycznych, jak i nauk ścisłych. Podstawę programów nauczania stanowią Koran oraz życie i działalność proroka Mahometa ${ }^{65}$.Z zawartych w Koranie słów: Zaprawdę wasz Pan jest dobrotliwy [...] On stworzyt konie, muty i osty, abyście ich dosiadali, a także dla ozdoby. I on stwarza to, czego wy nie znacie (Sura XVI, 7-8), muzułmańscy egzegeci wywodzą nie tylko rozwój pociągów, samochodów czy samolotów, ale także wiele innych odkryć naukowych ${ }^{66}$. Powołując się na Hodżę Efendiego, polski biograf stwierdza, że Koran wypowiada się na wszystkie tematy (podane w nim zostaty podstawy fizyki, chemii, matematyki) oraz ukazuje prawdziwy obraz cztowieka. I dalej: Ksiega ta stanowi fundament wszelkiej wiedzy, która posiąś́ może cztowiek. Jest także swego rodzaju dzietem pedagogicznym, podajacym reguty wychowania każdego cztowieka ${ }^{67}$. Ostatnie dwa zdania zdają się zgadzać z poglądem Sakowicza, ponieważ nie ma przy nich odwołania do dzieł Gülena. Z powyższymi tezami również nie jest łatwo prowadzić polemikę i dlatego wolę z niej świadomie zrezygnować, albowiem uważam, że tezy autora mówią same za siebie.

Przytoczone powyżej opinie i stanowiska wyłożone przez Eugeniusza Sakowicza w zasadzie wymykają się naukowej analizie. W niektórych miejscach starałem się przywołać kontrargumenty, które z nieznanych mi powodów pomijał polski badacz twórczości Hodży Efendiego. Rzadko zdarza się, aby autor z odmiennego kręgu religijnego tak bezkrytycznie prezentował bohatera swoich dociekań naukowych. Analizowana praca prezentu-

63 E. Sakowicz, Muzutmańska edukacja i wychowanie..., s. 109.

64 Tamże, s. 70.

65 Na temat osiągnięć Mahometa na gruncie nauki por. M.F. Gülen, Muhammad, wystannik Boga. Nowe spojrzenie, przeł. J. Surdel, Białystok 2007, s. 61-65. Znaleźć tam można wypowiedzi Mahometa na temat epidemiologii, bakteriologii, zdrowego żywienia, szkodliwości spożywania alkoholu. Pierwsze wydanie tej książki ukazało się w USA w 2005 r. Szkoda, że polski biograf nie przytoczył ich szerzej, zwłaszcza że cytuje wspomnianą pracę kilkukrotnie.

66 Por. R. Al-Maghribi, Czy Koran jest stowem Bożym?..., s. 149, a także komentarz J. Bielawskiego w: Koran, s. 886.

67 E. Sakowicz, Muzutmańska edukacja i wychowanie..., s. 72. 
je zestaw banałów i truizmów pozbawionych wszelkiego krytycyzmu, pełnych uwielbienia dla postaci bohatera i jego dzieła, zdaniem autora analizowanej książki jednego z największych autorytetów życia religijnego i humanistycznego we wspótczesnym świecie. Ta ucieczka od krytyki jest zastanawiająca i w mojej ocenie - nie do przyjęcia na gruncie nauki. $Z$ tych powodów wydaje mi się uprawnione stanowisko wyrażone w tytule moich uwag do recenzowanej pracy: apologia to za mało. Mamy do czynienia z klasyczną hagiografią.

\section{BIBLIOGRAFIA}

\section{Źródła}

Koran, przet. i koment. J. Bielawski, Warszawa 1986.

\section{Literatura}

Ahmed Q., W kraju niewidzialnych kobiet, przet. E. Krawczyk, Warszawa 2013.

Akkoc R., A Parallel State within Turkey? How the Country's Democracy Came under Attack from Two Men's Rivalry, [online] http://www.telegraph.co.uk/news/worldnews/europe/ turkey/11397876/A-parallel-state-within-Turkey-How-the-countrys-democracy-came-under-attack-from-two-mens-rivalry.html.

Al-Maghribi R., Czy Koran jest stowem Bożym? Świadectwo nawrócenia muzutmanina, Poznań 2011.

Aslan R., Nie ma Boga oprócz Allaha. Powstanie, ewolucja i przysztość islamu, przeł. P. Gołębiowski, Warszawa 2014.

Bury J., Kasprzak J., Prawo karne islamu, Warszawa 2007.

Darwish N., Okrucieństwo w majestacie prawa. Prześladowanie kobiet w świecie islamu, Warszawa 2011.

Górak-Sosnowska K., Muzutmańska kultura konsumpcyjna, Warszawa 2011.

Gülen M.F., Muhammad, wystannik Boga. Nowe spojrzenie, przel. J. Surdel, Białystok 2007.

Hallaq W.B., What is Sharia?, „Yearbook of Islamic and Middle Eastern Law” 2005-2006, Vol. 12.

Hoffman M., Islam jako alternatywa, [online] http://www.ipdirect.home.pl $/ \mathrm{kmp} /$ publication/ islam_jako_alternatywa/16\%20islam\%20jako\%20alternatywa\%20islamska\%20jurysprudencja.htm.

Ibn Warraq, Dlaczego nie jestem muzutmaninem?, Warszawa 2013.

Khan M.A., Islamic Jihad. A Legacy of Forced Conversion, Imperialism and Slavery, New York 2009.

Krawczyk R., Islam jako system spoteczno-polityczny, Warszawa 2013.

Landowski Z., Polityczny wymiar islamu we wspótczesnych konstytucjach, Warszawa 2013.

Mattson I., Qur'an. Historia i rola Świętej Księgi w życiu muzutmanów, przeł. K. Makaruk, M. Turowski, Wrocław 2013.

Nosowski J., Teologia Koranu. Wyktad systematyczny, Warszawa 1970.

Paolucci G., Eid C., Islam. Sto pytań. Odpowiada Samir Khalil Samir, przeł. K. Klauza, Warszawa 2004. 
Pasamonik B., Rola ptci w integracji europejskich muzutmanów, Kraków 2013.

Pilch T., Bauman T., Zasady badań pedagogicznych, Warszawa 2010.

Sadowski M., Dżihad - święta wojna w islamie, „Przegląd Bezpieczeństwa Wewnętrznego” 2013, nr 8(5).

Sadowski M., Naskh - metoda usuwania sprzeczności w prawie islamu, Wrocław 2014, Wroctawskie Studia Erazmiańskie, z. 8.

Sakowicz E., Muzutmańska edukacja i wychowanie. Pedagogiczna wizja M. Fethullaha Gülena, Białystok 2014.

Scarabel A., Islam, przeł. K. Stopa, Kraków 2004.

Sharon-Krespin R., Fethullah Gülen's Grand Ambition. Turkey's Islamist Danger, [online] http://www.meforum.org/2045/fethullah-Gülens-grand-ambition.

Stakelbeck E., The Gülen Movement. A New Islamic World Order?, [online] http://www.cbn. com/cbnnews/world/2011/May/The-Gülen-Movement-The-New-Islamic-World-Order.

Teissier H., Chrześcijanin wobec islamu, [w:] E. Sakowicz, Czy islam jest religia terrorystów?, Kraków 2002.

św. Tomasz z Akwinu, Summa contra gentiles. Prawdy wiary chrześcijańskiej w dyskusji z poganami, innowiercami i btądzącymi, t. 1, Poznań 2003.

Torrey C.C., The Jewish Foundation of Islam, New York 1933.

Uniwersalny stownik jezyka polskiego, t. 1, 4, red. S. Dubisz, Warszawa 2003.

Weigel G., Wiara, rozum i wojna z dzihadyzmem, Warszawa 2009.

Widy-Behiese M., Tożsamość europejskich muzutmanów w myśli Tariqa Ramadana, Warszawa 2012.

Williams P.L., FBI Launches Investigation of Gülen and His Movement, [online] http://canadafreepress.com/article/34766.

Witkowski I., Supertajne bronie islamu, Warszawa 1999.

Woodall M., Gatti C., [online] http://articles.philly.com/2011-03-20/news/29148147_1_ Gülen-schools-Gülen-followers-charter-schools.

Dr hab. Mirosław SADOWSKI, prof. nadzw. UWr - kierownik Pracowni Badań Praw Orientalnych na Wydziale Prawa, Administracji i Ekonomii Uniwersytetu Wrocławskiego. Autor dwóch monografii, współautor siedmiu książek. Autor około 200 artykułów i opracowań naukowych. Czynny uczestnik (autor referatów) na kilkudziesięciu konferencjach naukowych. Recenzent dwóch rozpraw habilitacyjnych i dziewięciu rozpraw doktorskich. Jego badania mieszczą się w obszarze doktryn politycznych i prawnych, historii gospodarczej, praw człowieka i wielkich religii współczesnego świata, ze szczególnym uwzględnieniem muzułmańskiej koncepcji prawa i państwa. Aktualny nurt jego zainteresowań to prawo i państwo w religiach monoteistycznych, ze szczególnym uwzględnieniem islamu i wpływu, jaki religia ta wywiera na tworzenie i stosowanie prawa oraz panujący model ustrojowy w badanych państwach, zarówno muzułmańskich, jak i niemuzułmańskich. Zajmuje się islamskim prawem rodzinnym, cywilnym i karnym. Ponadto, w kontekście islamu, stara się odpowiedzieć na pytanie, czy terroryzm islamski ma konotacje religijne. 